\title{
Pengaruh Pengalaman Auditor dan Independensi Pada Kualitas Audit Dengan Etika Auditor Sebagai Variabel Moderasi
}

\author{
Putu Delsi Nia Sarca ${ }^{1}$ \\ Ni Ketut Rasmini ${ }^{2}$ \\ ${ }^{1,2}$ Fakultas Ekonomi dan Bisnis Universitas Udayana (Unud), Bali, Indonesia \\ e-mail: delsi.jantuk@gmail.com
}

\begin{abstract}
ABSTRAK
Tujuan penelitian ini untuk mengetahui pengaruh pengalaman auditor dan independensi pada kualitas audit dengan etika auditor sebagai variabel moderasi. Penelitian ini dilakukan pada seluruh KAP yang masih beroperasi di Provinsi Bali. Teknik pengambilan sampel yang digunakan adalah purposive sampling. Data dianalisis dengan menggunakan uji Moderated Regression Analysis (MRA). Hasil analisis menunjukkan bahwa pengalaman auditor berpengaruh positif pada kualitas audit, independensi auditor berpengaruh positif pada kualitas audit, etika auditor memperkuat pengaruh pengalaman auditor pada kualitas audit dan etika auditor memperkuat pengaruh independensi pada kualitas audit di KAP Provinsi Bali.

Kata kunci: Pengalaman auditor, independensi, etika auditor, kualitas audit
\end{abstract}

\begin{abstract}
The purpose of this study was to determine the effect of auditor experience and independence on audit quality with auditor ethics as a moderating variable. This research was conducted on all KAPs that are still operating in Bali Province. The sampling technique used was purposive sampling. Data were analyzed using the Moderated Regression Analysis (MRA) test. The results of the analysis show that the auditor's experience has a positive effect on audit quality, auditor independence has a positive effect on audit quality, auditor ethics strengthens the influence of auditor experience on audit quality and auditor ethics reinforces the influence of independence on audit quality in KAP Bali Province.

Keywords: Auditor experience, independence, auditor ethics, audit quality
\end{abstract}

\section{PENDAHULUAN}

Perkembangan dunia usaha dewasa ini telah menjelaskan bahwa kebutuhan akan audit semakin meningkat, hal ini dikarenakan informasi perusahaan semakin terbuka dimana kepemilikan terhadap entitas usaha yang terdiri dari saham dan investasi dapat dimiliki oleh berbagai pihak. Pemilik dan pengelola (manajemen) yang terpisah mengharuskan laporan keuangan yang dibuat dan disajikan oleh 
manajemen kepada pemilik diperiksa kebenaran dan kewajaran sesuai dengan aturan dan ketentuan yang berlaku. Audit atas laporan terutama diperlukan oleh perusahaan berbentuk Perseroan Terbatas (PT) yang pemiliknya adalah para pemegang saham. Para Pemegang saham biasanya akan meminta pertanggungjawaban manajemen dalam bentuk laporan keuangan setahun sekali dalam Rapat Umum Pemegang Saham (Agoes, 2017).

Laporan keuangan berkualitas bila memenuhi kriteria relevansi atau keberpautan (relevance) dan reliabilitas atau keterandalan (reliability). Kriteria relevansi dipenuhi bila laporan keuangan mempunyai nilai prediktif (predictive value) dan atau nilai balikan (feedback value) dan disajikan tepat pada waktunya. Kriteria reliability bertumpu pada keterujian (verifiability), kenetralan (neutrality) dan ketepatan penyimbolan (representation faithfullness). Pemakai laporan keuangan menaruh kepercayaan yang cukup besar terhadap hasil pekerjaan auditor dalam mengaudit laporan keuangan (Agoes, 2017). Perusahaan yang diaudit dengan kualitas audit yang lebih tinggi memiliki koefisien stabilitas lebih akrual dan menghasilkan laporan keuangan yang lebih handal (Smii, 2016).

Profesi Akuntan Publik diseluruh dunia merupakan profesi yang menghadapi resiko yang sangat tinggi. Hampir semua akuntan publik menyadari mereka harus memberikan jasa profesionalnya sesuai dengan standar profesional akuntan publik, mentaati kode etik akuntan publik dan memiliki standar pengendalian mutu. Sejak terjadinya kasus Enron, World Comp dan Xerok menyebabkan ditutupnya KAP Arthur Anderson, kepercayaan masyarakat terhadap profesi akuntan publik menurun drastis. KAP Anderson seharusnya 
menjunjung tinggi independensi dan profesionalisme tetapi melakukan pelanggaran terhadap kode etik profesi. Pemerintah Amerika mengeluarkan Sarbanes Oxley Act untuk mencegah terjadinya kasus serupa (Agoes, 2017).

Kepercayaan yang besar dari pemakai laporan keuangan yang diberikan oleh akuntan publik mengharuskan akuntan publik memperhatikan kualitas audit yang dihasilkannya. Audit digunakan untuk memberikan kepastian yang dibutuhkan bagi investor saat mengandalkan laporan keuangan yang diaudit. Lebih tepatnya, peran auditing adalah mengurangi asimetri informasi pada nomor akuntansi, dan untuk meminimalkan kerugian residual akibat oportunisme manajer dalam keuangan pelaporan (Adeyemi \& Fagbemi, 2010).

Pertanyaan masyarakat tentang kualitas-kualitas audit yang dihasilkan akuntan publik semakin besar setelah terjadi banyak skandal yang melibatkan akuntan publik. Kasus yang menimpa akuntan publik Justinus Aditya Sidharta yang diindikasi melakukan kesalahan dalam mengaudit laporan keuangan PT. Great River International, Tbk menjadi sorotan masyarakat. Kasus tersebut muncul setelah adanya temuan auditor investigasi dari Bapepam yang menemukan indikasi penggelembungan account penjualan, piutang dan aset hingga ratusan milyar rupiah pada laporan keuangan Great River yang menyebabkan perusahaan tersebut akhirnya kesulitan arus kas dan gagal dalam membayar utang. Menteri Keuangan RI terhitung sejak tanggal 28 November 2006 telah membekukan izin akuntan publik Justinus Aditya Sidharta selama dua tahun karena telah terbukti melakukan pelanggaran terhadap Standar Profesi Akuntan Publik (SPAP) 
berkaitan dengan laporan audit atas Laporan Keuangan Konsolidasi PT. Great River tahun 2003 (Tjun, Marpaung, \& Setiawan, 2012).

Skandal ini menunjukkan bahwa independensi dan etika auditor sebagai hal yang krusial dalam rangka melaporkan kinerja manajemen perusahaan (klien) terhadap pihak lain yang berkepentingan. Auditor sebagai Akuntan Publik bertanggung jawab terhadap para pemegang saham untuk menjamin penanaman modal yang mereka lakukan sebagai hasil pertimbangan dari laporan auditor. Auditor sebagai akuntan publik bertanggung jawab terhadap pegawai perusahaan untuk menjamin mereka bekerja dengan meyakini laporan auditor tidak merugikan pegawai. Auditor sebagai Akuntan Publik bertanggung jawab terhadap masyarakat untuk menjamin mereka yang ingin menanamkan modal sebagai hasil pertimbangan dari laporan auditor (M. Nizarul Alim, Trisni Hapsari, 2007).

(Muliani, Sujana, \& Purnamawati, 2015) sebagai penunjang keberhasilan dalam menjalankan tugas dan fungsinya dengan baik, sangatlah diperlukan kinerja auditor yang baik dan berkualitas. Tercapainya kinerja yang baik tidak terlepas dari kualitas sumber daya manusia (SDM) yang baik pula. Sumber daya manusia adalah faktor penting demi terciptanya laporan keuangan yang berkualitas. Kualitas SDM auditor dapat ditentukan dari pengalaman kerja auditor, independensi dan etika profesi auditor. (Syahmina, 2016), juga menyatakan bahwa kualitas audit yang baik dapat dicapai jika auditor menerapkan standarstandar audit dan prinsip-prinsip audit, bersikap bebas dan tidak memihak, bersikap profesional, patuh terhadap hukum serta mentaati kode etik profesi akuntan. 
Pengalaman kerja erat kaitannya dengan lama masa kerja dan banyaknya pemeriksaan yang dilakukan auditor. Pengujian pengaruh variabel pengalaman auditor terhadap kualitas audit yang dilakukan oleh (Hanjani \& Rahardja, 2014) menemukan pengalaman auditor memiliki pengaruh positif yang signifikan terhadap kualitas audit. Semakin berpengalaman auditor maka akan semakin baik kualitas audit yang dilakukannya. Auditor yang berpengalaman dinilai kinerjanya lebih optimal serta lebih mampu mendeteksi, memahami bahkan mencari penyebab dari munculnya kecurangan-kecurangan daripada auditor yang tidak berpengalaman, sehingga kualitas audit yang dihasilkan pun akan lebih baik daripada auditor yang tidak berpengalaman.

Pengalaman audit terbukti memiliki pengaruh positif namun tidak signifikan pada Kualitas Audit Studi pada Kantor Akuntan Publik (KAP) di Bali (Septiani \& Juliarsa, 2014). (Janrosl, 2017) mendapat hasil bahwa pengalaman kerja auditor tidak berpengaruh terhadap kualitas hasil audit pada Kantor Akuntan Publik. Pengalaman akuntan publik akan terus meningkat seiring dengan makin banyaknya audit yang dilakukan serta kompleksitas transaksi keuangan perusahaan yang diaudit sehingga akan menambah dan memperluas pengetahuannya di bidang akuntansi dan auditing.

Auditor perlu bersikap independen dimana untuk mematangkan pertimbangan dalam menyusun laporan hasil pemeriksaan audit juga untuk mencapai harapan para klien yakni audit yang berkualitas. (Tjun et al., 2012) berpendapat bahwa independensi dapat diartikan sikap mental yang bebas dari pengaruh, tidak dikendalikan oleh pihak lain, tidak bergantung pada orang lain. 
Independensi juga berarti adanya kejujuran dalam diri auditor dalam mempertimbangkan fakta dan adanya pertimbangan yang objektif tidak memihak dalam diri auditor dalam merumuskan dan menyatakan pendapatnya. Independensi auditor mendasari kepercayaan pasar tehadap kredibilitas dan integritas laporan keuangan perusahaan (Hassan, 2014). Kepercayaan yang diberikan oleh klien kepada akuntan publik dalam melaksanakan audit dan para pengguna laporan keuangan agar dapat membuktikan kewajaran laporan keuangan yang telah disusun oleh klien .

Beberapa penelitian tentang pengaruh independensi pada kualitas auditor menemukan hubungan yang bervariasi. Hasil penelitian (Dewi, 2016), (Halim, Sutrisno, \& Achsin, 2014) dan (A O Enofe, Okunega, \& Ediae, 2013) menemukan bahwa independensi berpengaruh positif pada kualitas audit, yaitu semakin meningkat independensi auditor, maka kualitas audit juga meningkat. Hasil penelititian (Efendy, 2010) dan (Tjun et al., 2012), menunjukkan hasil berbeda bahwa independensi auditor tidak berpengaruh pada kualitas audit, sehingga independensi yang dimiliki auditor tidak menjamin apakah yang bersangkutan melakukan audit secara berkualitas.

Penelitian ini mengacu kepada SPAP 2016 dan Kode Etik Akuntan Profesional 2016. SPAP 2016 merupakan standar profesional akuntan publik terbaru yang menjadi standar acuan bagi akuntan publik. Kode Etik Akuntan Profesional 2016 merupakan pedoman dasar yang berisi prinsip-prinsip dasar etika yang digunakan untuk mematuhi dan menjalankan setiap aturan dalam SPAP. Etika sebagai salah satu unsur utama dari profesi menjadi landasan bagi 
akuntan dalam menjalankan kegiatan profesional. Akuntan mempunyai tanggung jawab untuk bertindak sesuai dengan kepentingan publik. Ikatan Akuntan Indonesia (IAI) sebagai organisasi akuntan di Indonesia telah memiliki Kode Etik IAI yang merupakan amanah dari AD/ART IAI dan peraturan yang berlaku (Azza S. M. Gaballa et al., 2015).

Penelitian ini bertujuan untuk menguji dan memperoleh bukti empiris mengenai pengaruh pengalaman auditor, independensi, dan etika auditor pada kualitas audit. Teori atribusi merupakan grand theory yang digunakan dalam penelitian ini. Teori atribusi menjelaskan tentang perilaku seseorang. Teori atribusi digunakan karena peneliti akan melakukan studi empiris untuk mengetahui pengaruh pengalaman auditor, independensi dan etika auditor pada kualitas audit, khususnya pada karakteristik personal auditor itu sendiri. Pada dasarnya karakteristik personal seorang auditor merupakan salah satu penentu pada kualitas audit yang akan dilakukan, karena merupakan suatu faktor internal yang mendorong seseorang untuk melakukan suatu aktivitas. Model penelitian ini dapat dilihat pada Gambar 1 sebagai berikut. 


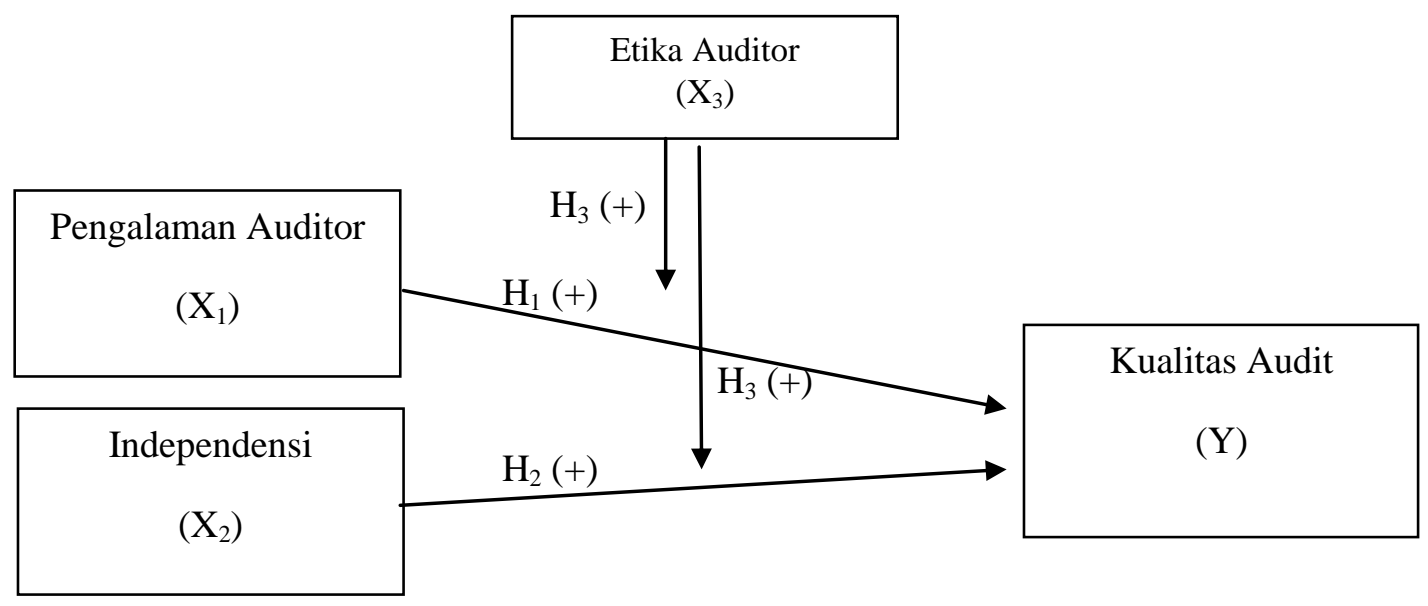

Sumber: Data diolah, 2018

\section{Gambar 1. Desain Penelitian}

Pengalaman bagi auditor dalam bidang audit berperan penting dalam meningkatkan pengetahuan dan keahlian diperoleh auditor dari pendidikan formalnya sehingga kualitas audit akan semakin baik seiring bertambahnya pengalaman (Pradipta \& Budiartha, 2016). Penelitian (Hanjani \& Rahardja, 2014), (Wiratama, 2015) dan (Usman, 2016), menunjukkan bahwa pengalaman kerja berpengaruh positif terhadap kualitas hasil pemeriksaan. Berdasarkan uraian di atas maka rumusan hipotesis adalah sebagai berikut:

$\mathrm{H}_{1}$ : Pengalaman auditor berpengaruh positif pada kualitas audit.

Penelitian yang dilakukan (Utama, 2015) menunjukkan bahwa independensi berpengaruh terhadap kualitas audit Kantor Akuntan Publik di Bali. Penelitian yang dilakukan oleh (Riduwan, 2017) dan (Augustine O Enofe, Mgbame, Aderin, \& Ehi-oshio, 2013) juga mendapatkan hasil bahwa independensi berpengaruh positif pada kualitas audit. Berdasarkan uraian di atas maka rumusan hipotesis adalah sebagai berikut:

$\mathrm{H}_{2}$ : Independensi berpengaruh positif pada Kualitas Audit. 
Pengalaman juga akan memberikan dampak pada setiap keputusan yang diambil dalam pelaksanaan audit sehingga diharapkan setiap keputusan yang diambil adalah merupakan keputusan yang tepat. Hal tersebut mengindikasikan bahwa semakin lama masa kerja yang dimiliki auditor maka auditor akan semakin baik pula kualitas audit yang dihasilkan (M. Nizarul Alim, Trisni Hapsari, 2007). Penelitian yang dilakukan oleh (Dewi, 2016) yang mendapatkan hasil interaksi pengalaman kerja dan kepatuhan etika auditor terhadap kualitas audit berpengaruh positif dengan tingkat signifikan. Berdasarkan uraian di atas maka rumusan hipotesis adalah sebagai berikut:

$\mathrm{H}_{3}$ : Etika auditor memperkuat pengaruh pengalaman pada kualitas audit.

Hasil penelitian (Hanjani \& Rahardja, 2014) dan (M. Nizarul Alim, Trisni Hapsari, 2007) menyatakan bahwa interaksi independensi dan etika auditor berpengaruh positif dan signifikan terhadap kualitas audit. Hubungan antara independensi dan etika auditor dapat mempengaruhi kualitas audit yang dihasilkan tergantung dari situasi yang dialami oleh seorang auditor dalam melakukan audit (Harjanto, 2014). Berdasarkan uraian di atas maka rumusan hipotesis adalah sebagai berikut:

$\mathrm{H}_{4}$ : Etika auditor memperkuat pengaruh independensi pada kualitas audit.

\section{METODE PENELITIAN}

Penelitian ini dilakukan pada seluruh KAP yang masih beroperasi di Provinsi Bali. Objek penelitian ini adalah kualitas audit yang dipengaruhi pengalaman auditor dan independensi serta dimoderasi oleh etika auditor pada Kantor Akuntan 
Publik. Terdapat 9 (sembilan) Kantor Akuntan Publik di Provinsi Bali yang terdaftar dalam Direktori yang diterbitkan oleh Ikatan Akuntan Indonesia yang berlokasi di Provinsi Bali.

Adapun rangkuman variabel dan indikator yang digunakan dalam penelitian ini dapat dilihat pada Tabel 1 berikut.

Tabel 1.

Rangkuman Variabel dan Indikator Penelitian

\begin{tabular}{llc}
\hline Variabel & \multicolumn{1}{c}{ Indikator } & Referensi \\
\hline & 1) Melaporkan semua kesalahan klien & \\
& 2) Pemahaman terhadap sistem informasi klien & \\
3) Komitmen yang kuat dalam menyelesaikan audit & Dewi \\
Kualitas audit (Y) & 4) Berpedoman pada prinsip auditing dan prinsip akuntansi & $(2016)$ \\
& & dalam melakukan pekerjaan lapangan \\
& 5) Tidak percaya begitu saja terhadap pernyataan klien & \\
6) Sikap kehati-hatian dalam pengambilan keputusan & \\
Auditor $\left(\mathrm{X}_{1}\right)$ & 1) Lamanya auditor bekerja & Dewi \\
& 2) Banyaknya penugasan yang ditangani & $(2016)$ \\
Independensi $\left(\mathrm{X}_{2}\right)$ & 3) Banyaknya jenis perusahaan yang pernah diaudit & Dewi \\
& 1) Gangguan Pribadi & $(2016)$ \\
Etika Auditor $\left(\mathrm{X}_{3}\right)$ & 1) Tangguan Eksternal & Dewi \\
& 2) Integritas & $(2016)$ \\
\hline
\end{tabular}

Teknik pengambilan sampel yang digunakan adalah purposive sampling, dengan kriteria bahwa auditor sudah memiliki pengalaman audit minimal 1 (satu) tahun pada KAP di Bali. Auditor yang bekerja lebih dari 1 (satu) tahun diangggap sudah memiliki waktu dan pengalaman untuk beradaptasi dan menilai kondisi kerja lingkungan (Riduwan, 2017).

Metode pengumpulan data yang digunakan dalam penelitian ini adalah metode survei dengan teknik kuesioner. Kuesioner yang disebarkan berupa daftar pernyataan tertulis kepada responden mengenai pengalaman auditor, independensi, etika auditor dan kualitas audit. 
Data yang sudah terkumpul kemudian dianalisis menggunakan teknik analisis regresi moderasi (Moderated Regression Analysis). Sebelum melakukan analisis regresi, penelitian ini melakukan uji instrumen penelitian dengan menggunakan uji validitas dan reliabilitas, serta melakukan uji asumsi klasik agar variabel yang dioperasikan memenuhi persyaratan sehingga tidak menimbulkan hasil yang bias dalam pengujian. Setelah data dinyatakan layak uji, maka dilakukan analisis regresi moderasi dengan persamaan sebagai berikut :

$Y=\alpha+\beta_{1} X_{1}+\beta_{2} X_{2}+\beta_{3} X_{3}+\beta_{4} X_{1} X_{3}+\beta_{5} X_{2} X_{3}+\varepsilon$

Keterangan :

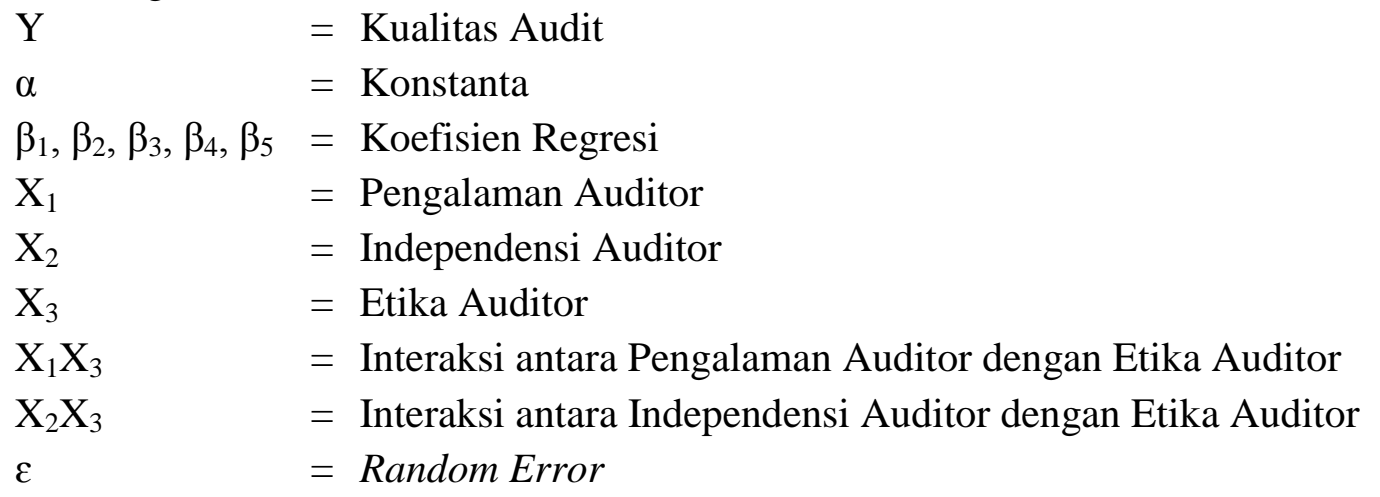

\section{HASIL DAN PEMBAHASAN}

Jumlah kuesioner yang disebar sebanyak 80 kuesioner namun tidak sepenuhnya kembali karena kebanyakan KAP memberikan batasan pengisian kuesioner dikarenakan auditor sibuk bertugas. Data pengiriman dan pengembalian kuisioner dapat dlihat dalam Tabel 2. 
Tabel 2.

Data Pengiriman dan Pengembalian Kuesioner

\begin{tabular}{llcc}
\hline No & \multicolumn{1}{c}{ Nama Kantor Akuntan Publik } & $\begin{array}{c}\text { Jumlah } \\
\text { Kuesioner } \\
\text { Tersebar }\end{array}$ & $\begin{array}{c}\text { Jumlah } \\
\text { Kuesioner } \\
\text { Kembali }\end{array}$ \\
\hline 1. $\quad$ KAP I Wayan Ramantha & 9 & 7 \\
2. $\quad$ KAP Drs. Johan, Malonda, Astika \& Rekan (Cab.) & 11 & 9 \\
3. KAP K. Gunarsa & 4 & 4 \\
4. $\quad$ KAP Drs. Ketut Budiartha, Msi & 10 & 5 \\
5. KAP Drs. Ketut Muliartha RM \& Rekan & 9 & 6 \\
6. KAP Drs. Sri Marmo Djogosarkoro \& Rekan & 19 & 11 \\
7. KAP Drs. Wayan Sunasdyana & 9 & 5 \\
8. KAP Arnaya dan Darmayasa & 2 & 2 \\
9. KAP Budhananda Munidewi & 7 & 7 \\
$\quad$ Total kuesioner yang disebar & 80 & 56 \\
$\quad$ Kuesioner yang dikembalikan & & 5 \\
Kuesioner yang tidak dapat digunakan & & 51 \\
Kuesioner yang digunakan dalam analisis & & \\
Tingkat pengembalian (Response Rate) & & \\
Kuesioner yang dikembalikan x 100\% & & \\
Kuesioner yang dikirim & & $60 \%$ \\
Tingkat Pengembalian yang digunakan Useable Response Rate & & \\
Kuesioner yang diolah x 100\% & & \\
\hline Sumber: Data diolah, 2018 & &
\end{tabular}

Tabel 2 menunjukkan bahwa dari 80 kuisioner yang disebarkan, terdapat 24

kuisioner yang tidak kembali, dan sebanyak 5 eksemplar tidak dapat digunakan karena pengalaman kerja di bawah 1 tahun sehingga hanya sejumlah 51 kuesioner yang dapat digunakan. Penelitian ini layak untuk dilanjutkan karena berdasarkan central limit theorem menyatakan jumlah minimal sampel untuk mencari kurva normal setidaknya mencapai nilai minimal 30 responden (Siregar, 2017)

Karakteristik responden pada penelitian ini merupakan profil dari responden yang berpartisipasi dalam pengisian kuesioner penelitian ini. Profil responden menerangkan jenis kelamin, jabatan responden, lama bekerja sebagai auditor dan pendidikan terakhir responden dalam Kantor Akuntan Publik tempatnya bekerja. Karakteristik responden dapat dilihat pada Tabel 3. 
Tabel 3.

Karakteristik Responden

\begin{tabular}{|c|c|c|c|}
\hline No & Keterangan & Jumlah & Persentase \\
\hline \multirow[t]{4}{*}{1.} & Jenis Kelamin : & & \\
\hline & - Pria & 22 & 43,14 \\
\hline & - Wanita & 29 & 56,86 \\
\hline & Jumlah & 51 & $100 \%$ \\
\hline \multirow[t]{5}{*}{2.} & Jabatan : & & \\
\hline & - $\quad$ Partner & 1 & 1,96 \\
\hline & - Senior & 25 & 49,02 \\
\hline & - Junior & 25 & 49,02 \\
\hline & Jumlah & 51 & $100 \%$ \\
\hline \multirow[t]{5}{*}{3.} & Lama bekerja sebagai auditor & & \\
\hline & $-\quad<1$ tahun & 0 & 0 \\
\hline & - $1 \mathrm{~s} / \mathrm{d} 10$ tahun & 51 & 100 \\
\hline & $->10$ tahun & 0 & 0 \\
\hline & Jumlah & 51 & $100 \%$ \\
\hline \multirow[t]{6}{*}{4.} & Jenjang pendidikan : & & \\
\hline & - D3 & 1 & 1,96 \\
\hline & $-\quad S 1$ & 39 & 76,47 \\
\hline & - $\quad$ S2 & 11 & 21,57 \\
\hline & S3 & 0 & 0 \\
\hline & Jumlah & 51 & $100 \%$ \\
\hline
\end{tabular}

Sumber: Data Diolah, 2018

Berdasarkan Tabel 3 nampak bahwa responden di dominasi oleh wanita $(56,86 \%)$ dengan masa kerja selama 1 sampai dengan 10 tahun. Adapun jenjang pendidikan responden dominan adalah $\mathrm{S} 1(76,47 \%)$, dan sisanya pada jenjang S2 $(21,57 \%)$ dan D3 (1,96\%). Apabila ditinjau berdasarkan jabatan responden masing-masing sebesar 49,02\% adalah senior dan junior auditor, sedangkan $1,96 \%$ adalah partner.

Data kuisioner yang sudah terkumpul selanjutnya diuji kelayakannya menggunakan uj validitas dan reliabilitas. Suatu kuesioner dikatakan valid jika tiap pertanyaan dalam kuesioner mampu mengungkapkan sesuatu yang akan diukur oleh kuesioner tersebut. Uji validitas dilakukan dengan bantuan program SPSS dengan menghitung korelasi antara skor masing-masing butir pernyataan dengan total skor sehingga didapat nilai Pearson Correlation. Untuk jumlah 
sampel sebanyak 51 nilai $\mathrm{r}$ tabel Product Moment adalah sebesar 0,344 dengan tingkat signifikansi 5\%. Kuesioner dengan dikatakan valid jika nilai Pearson Correlation positif dan lebih besar dari nilai r tabel Product Moment (Sugiyono, 2017).

Tabel 4.

Hasil Uji Validitas

\begin{tabular}{|c|c|c|c|c|c|c|c|}
\hline \multicolumn{2}{|c|}{$\begin{array}{l}\text { Kualitas Audit } \\
\text { (Y) }\end{array}$} & \multicolumn{2}{|c|}{$\begin{array}{c}\text { Pengalaman Kerja } \\
\left(\mathrm{X}_{1}\right)\end{array}$} & \multicolumn{2}{|c|}{$\begin{array}{l}\text { Independensi } \\
\left(\mathrm{X}_{2}\right)\end{array}$} & \multicolumn{2}{|c|}{$\begin{array}{c}\text { Etika Auditor } \\
\left(\mathrm{X}_{3}\right)\end{array}$} \\
\hline \multicolumn{8}{|c|}{ Pearson Correlation } \\
\hline $\mathrm{Y}_{1.1}$ & 0,554 & $\mathrm{X}_{1.1}$ & 0,917 & $\mathrm{X}_{2.1}$ & 0,645 & $\mathrm{X}_{3.1}$ & 0,617 \\
\hline $\mathrm{Y}_{1.2}$ & 0,786 & $\mathrm{X}_{1.2}$ & 0,790 & $\mathrm{X}_{2.2}$ & 0,742 & $\mathrm{X}_{3.2}$ & 0,848 \\
\hline $\mathrm{Y}_{1.3}$ & 0,679 & $\mathrm{X}_{1.3}$ & 0,830 & $\mathrm{X}_{2.3}$ & 0,617 & $\mathrm{X}_{3.3}$ & 0,738 \\
\hline $\mathrm{Y}_{1.4}$ & 0,720 & $\mathrm{X}_{1.4}$ & 0,832 & $\mathrm{X}_{2.4}$ & 0,477 & $\mathrm{X}_{3.4}$ & 0,850 \\
\hline $\mathrm{Y}_{1.5}$ & 0,420 & $\mathrm{X}_{1.5}$ & 0,432 & $\mathrm{X}_{2.5}$ & 0,788 & $\mathrm{X}_{3.5}$ & 0,604 \\
\hline $\mathrm{Y}_{1.6}$ & 0,668 & $\mathrm{X}_{1.6}$ & 0,895 & $\mathrm{X}_{2.6}$ & 0,742 & $X_{3.6}$ & 0,765 \\
\hline $\mathrm{Y}_{1.7}$ & 0,749 & $\mathrm{X}_{1.7}$ & 0,695 & & & $\mathrm{X}_{3.7}$ & 0,714 \\
\hline $\mathrm{Y}_{1.8}$ & 0,689 & $\mathrm{X}_{1.8}$ & 0,427 & & & $\mathrm{X}_{3.8}$ & 0,831 \\
\hline $\mathrm{Y}_{1.9}$ & 0,786 & $\mathrm{X}_{1.9}$ & 0,852 & & & $\mathrm{X}_{3.9}$ & 0,729 \\
\hline $\mathrm{Y}_{1.0}$ & 0,621 & $\mathrm{X}_{1.0}$ & 0,851 & & & $\mathrm{X}_{3.0}$ & 0,671 \\
\hline $\mathrm{Y}_{1.11}$ & 0,766 & & & & & $\mathrm{X}_{3.11}$ & 0,837 \\
\hline $\mathrm{Y}_{1.12}$ & 0,739 & & & & & $\mathrm{X}_{3.12}$ & 0,691 \\
\hline $\mathrm{Y}_{1.13}$ & 0,803 & & & & & $\mathrm{X}_{3.13}$ & 0,813 \\
\hline$Y_{1.14}$ & 0,727 & & & & & & \\
\hline
\end{tabular}

Tabel 4 menyajikan hasil uji validitas instrument penelitian untuk variabel kualitas audit, pengalaman kerja, independensi dan etika auditor. Masing-masing variabel pada Tabel 3 memiliki nilai pearson correlation lebih dari 0,344 yang menunjukkan bahwa pernyataan dalam kuesioner telah memenuhi syarat sehingga dapat dikatakan valid.

Selanjutnya untuk menunjukkan sejauh mana suatu alat pengukur dapat dipercaya atau diandalkan dalam penelitan ini menggunakan uji reliabilitas. Uji ini dilakukan terhadap instrumen dengan koefisien cronbach's alpha, apabila instrumen yang digunakan lebih besar dari 0,60 maka instrumen tersebut 
dinyatakan reliabel. Hasil uji reliabilitas instrument penelitian dapat dlihat pada Tabel 5.

Tabel 5.

Hasil Uji Reliabilitas

\begin{tabular}{lcc}
\hline \multicolumn{1}{c}{ Variabel } & Nilai Cronbach's Alpha & Keterangan \\
\hline Kualitas Audit $(\mathrm{Y})$ & 0,917 & Reliabel \\
Pengalaman Kerja $\left(\mathrm{X}_{1}\right)$ & 0,918 & Reliabel \\
Independensi $\left(\mathrm{X}_{2}\right)$ & 0,745 & Reliabel \\
Etika Auditor $\left(\mathrm{X}_{3}\right)$ & 0,935 & Reliabel \\
\hline
\end{tabular}

Sumber: Data diolah, 2018

Tabel 5 menunjukkan bahwa instrumen variabel kualitas audit, pengalaman kerja , independensi dan etika auditor memiliki koefisien Cronbach's Alpha lebih besar dari 0,60 sehingga pernyataan dalam kuesioner tersebut reliabel.

Rentang interval untuk mengukur kriteria masing-masing variabel yaitu :

Nilai Interval $\quad$ Skor maksimum - Skor minimun $=4-1=3$

Range : $\quad \frac{\text { Nilai Interval }}{\text { Jumlah Kelas }}=\frac{3}{4}=0,75$

Skor pada penelitian ini memiliki nilai tertinggi maksimal 4 dan terendah minimal 1, sehingga dapat disusun kriteria pengukuran sebagai berikut :

Tabel 6.

Nilai Interval dan Kriteria Variabel Penelitian

\begin{tabular}{cc}
\hline Nilai Skor & Kriteria Variabel Penelitian \\
\hline $1,00-1,75$ & Sangat Rendah \\
$1,76-2,50$ & Rendah \\
$2,51-3,25$ & Tinggi \\
$3,26-4,00$ & Sangat Tinggi \\
\hline
\end{tabular}

Sumber : Data diolah, 2018

Kriteria pengukuran tersebut menunjukkan bahwa semakin tinggi nilai ratarata yang diperoleh menunjukkan semakin baik tanggapan responden terhadap item maupun variabel tersebut. Adapun hasil analisis deskriptif untuk mengetahui penilaian responden pada setiap variabel dapat dilihat pada Tabel 7. 
Tabel 7.

Hasil Statistik Deskriptif

\begin{tabular}{lccrrr}
\hline \multicolumn{1}{c}{ Variabel } & $\mathrm{N}$ & Min & \multicolumn{1}{c}{ Max } & \multicolumn{1}{c}{ Mean } & Std. Deviation \\
\hline Kualitas Audit $(\mathrm{Y})$ & 51 & 2,43 & 3,79 & 3,1408 & 0,34560 \\
Pengalaman Auditor $\left(\mathrm{X}_{1}\right)$ & 51 & 2,50 & 4,00 & 3,2529 & 0,43834 \\
Independensi $\left(\mathrm{X}_{2}\right)$ & 51 & 2,33 & 4,00 & 3,2478 & 0,37109 \\
Etika Auditor $\left(\mathrm{X}_{3}\right)$ & 51 & 2,46 & 4,00 & 3,2671 & 0,41486 \\
Interaksi $\mathrm{X}_{1} \mathrm{X}_{3}$ & 51 & 6,54 & 16,00 & 10,7069 & 2,36700 \\
Interaksi $\mathrm{X}_{2} \mathrm{X}_{3}$ & 51 & 6,10 & 15,33 & 10,6582 & 2,03859 \\
\hline
\end{tabular}

Sumber: Data diolah, 2018

Berdasarkan hasil uji statistik deskriptif pada Tabel 7 menunjukkan bahwa nilai rata-rata variabel kualitas audit sebesar 3,14 berada pada kriteria tinggi yaitu pada rentang nilai 2,51-3,25. Nilai rata-rata variabel pengalaman auditor sebesar 3,25 berada pada kriteria tinggi yaitu pada rentang nilai $2,51-3,25$. Nilai rata-rata variabel independensi auditor sebesar 3,25 berada pada kriteria sangat tinggi yaitu pada rentang nilai 2,51-3,25, maka dapat dikatakan bahwa secara keseluruhan auditor pada KAP di Provinsi Bali sudah memiliki sikap independensi yang tinggi. Selanjutnya, nilai rata-rata variabel etika auditor sebesar 3,27 berada pada kriteria sangat tinggi yaitu pada rentang nilai 3,26-4,00,

Sebelum dilakukan analisis regresi moderasi, data dalam penelitian ini diuji kelayakannya menggunakan uji asumsi klasik, dengan hasil sebagai berikut:

Tabel 8.

Rangkuman Hasil Uji Asumsi Klasik

\begin{tabular}{cclc}
\hline \multicolumn{2}{c}{ Hasil Uji Normalitas } & \multicolumn{1}{c}{ Hasil Uji Heteroskedastisitas } \\
\hline $\begin{array}{c}\text { Kolmogorov } \\
\text { Smirnov Z }\end{array}$ & $\begin{array}{c}\text { Asymp. } \\
\text { Sig (2-tailed) }\end{array}$ & \multicolumn{1}{c}{ Variabel } & Sig. \\
\hline & & Pengalaman $\left(\mathrm{X}_{1}\right)$ & 0,265 \\
\multirow{2}{*}{0,922} & Independensi $\left(\mathrm{X}_{2}\right)$ & 0,367 \\
& \multirow{2}{*}{0,363} & Etika Auditor $\left(\mathrm{X}_{3}\right)$ & 0,603 \\
& & Pengalaman, Etika Auditor $\left(\mathrm{X}_{1} \mathrm{X}_{3}\right)$ & 0,305 \\
& Independensi, Etika Auditor $\left(\mathrm{X}_{2} \mathrm{X}_{3}\right)$ & 0,419 \\
\hline \multicolumn{2}{l}{ Sumber : Data diolah, 2018} &
\end{tabular}

Berdasarkan Tabel 8 dapat dilihat bahwa nilai signifikan dari model persamaan memiliki probabilitas (sig) sebesar 0,363. Hal ini menunjukkan bahwa 
model regresi terdistribusi secara normal karena memiliki nilai Asymp. Sig. (2tailed) lebih besar dari 0,05. Sedangkan, hasil uji heteroskedastisitas menunjukkan bahwa setiap variabel sudah memiliki nilai signifikansi yang lebih besar dari 0,05 yang berarti bahwa tidak terdapat heteroskedastisitas pada penelitian ini.

Tabel 9.

Rangkuman Hasil Uji Moderated Regression Analysis (MRA)

\begin{tabular}{|c|c|c|c|c|c|}
\hline \multirow[t]{2}{*}{ Variabel } & \multicolumn{2}{|c|}{$\begin{array}{c}\text { Unstandardized } \\
\text { Coefficients }\end{array}$} & \multirow{2}{*}{$\begin{array}{c}\text { Standardized } \\
\text { Coefficients } \\
\text { Beta }\end{array}$} & \multirow[t]{2}{*}{$\mathrm{T}$} & \multirow[t]{2}{*}{ Sig. } \\
\hline & $\mathrm{B}$ & Std. Error & & & \\
\hline Constant & $-6,595 \mathrm{E}-7$ & 0,084 & & 0,000 & 1,000 \\
\hline Pengalaman $\left(\mathrm{X}_{1}\right)$ & 3,207 & 1,351 & 3,207 & 2,374 & 0,022 \\
\hline Independensi $\left(\mathrm{X}_{2}\right)$ & 2,504 & 1,022 & 2,504 & 2,450 & 0,018 \\
\hline Etika Auditor $\left(\mathrm{X}_{3}\right)$ & 0,456 & 0,678 & 0,456 & 0,673 & 0,505 \\
\hline Interaksi $\mathrm{X}_{1} \mathrm{X}_{3}$ & 4,806 & 2,199 & 4,806 & 2,186 & 0,034 \\
\hline Interaksi $\mathrm{X}_{1} \mathrm{X}_{3}$ & 5,120 & 1,780 & 5,120 & 2,877 & 0,006 \\
\hline Adjusted R Square & & & 0,638 & & \\
\hline F hitung & & & 18,593 & & \\
\hline Signifikansi F & & & 0,000 & & \\
\hline
\end{tabular}

Sumber : Data diolah, 2018

Hasil uji F (goodness of fit) pada Tabel 9 menunjukkan bahwa nilai signifikansi $\mathrm{P}$ value 0,000 lebih kecil dari $\alpha=0,05$, ini berarti model yang digunakan pada penelitian ini adalah layak. Hasil ini memberikan makna bahwa seluruh variabel independen dapat memprediksi atau menjelaskan fenomena kualitas audit pada KAP di Provinsi Bali sehingga dapat disimpulkan bahwa model dalam penelitian ini dikatakan layak untuk diteliti.

Berdasarkan hasil analisis regresi pada Tabel 8, maka dapat disusun persamaan regresi sebagai berikut:

$$
Y=3,207 X_{1}+2,504 X_{2}+0,456 X_{3}+4,806 X_{1} X_{3}+5,120 X_{2} X_{3}
$$

Hasil uji kelayakan model menunjukkan bahwa besarnya adjusted $\mathrm{R}^{2}$ (koefisien determinasi yang telah disesuaikan) pada Tabel 8 adalah 0,638. Ini 
berarti variasi kualitas audit $(\mathrm{Y})$ dipengaruhi oleh variasi pengalaman auditor $\left(\mathrm{X}_{1}\right)$, independensi $\left(\mathrm{X}_{2}\right)$, etika auditor $\left(\mathrm{X}_{3}\right)$ sebesar 63,8 persen dan sisanya sebesar 36,2 persen dipengaruhi oleh faktor lain yang tidak dijelaskan dalam model penelitian.

Berdasarkan hasil analisis pengaruh pengalaman auditor pada kualitas audit dalam Tabel 8 diperoleh nilai Signifikasi sebesar $0,022<0,050$ dengan nilai koefisien regresi positif sebesar 3,207. Hal ini berarti bahwa semakin banyak pengalaman yang dimiliki oleh auditor di KAP Provinsi Bali, maka akan semakin baik pula pandangan dan tanggapan auditor tentang informasi yang terdapat dalam laporan keuangan, sehingga dapat meningkatkan kualitas audit yang dihasilkan.

Hasil penelitian ini sesuai dengan hasil penelitian (Hanjani \& Rahardja, 2014) yang menyatakan bahwa pengalaman auditor berpengaruh positif pada kualitas audit yaitu semakin banyak pengalaman kerja seorang auditor maka semakin meningkat kualitas auditnya. Hasil penelitian ini juga mendukung temuan penelitian (Utama, 2015), (Azza S. M. Gaballa et al., 2015) dan (Hassan, 2014) yang menunjukkan bahwa pengalaman kerja berpengaruh positif terhadap kualitas hasil pemeriksaan laporan keuangan. Semakin tinggi pengalaman auditor, maka semakin mampu dan mahir auditor menguasai tugasnya sendiri maupun aktivitas yang diauditnya, sehingga auditor mampu menghadapi dan menyelesaikan hambatan maupun persoalan dalam pelaksanaan tugasnya, serta mampu mengendalikan kecenderungan emosional terhadap pihak yang diperiksa dan pada akhirnya akan dapat mengasilkan laporan audit yang berkualitas (Muliani et al., 2015)

Berdasarkan hasil analisis pengaruh independensi auditor pada kualitas 
audit pada Tabel 8 diperoleh nilai Signifikasi sebesar $0,018<0,05$ dengan nilai koefisien regresi positif sebesar 2,504. Hal ini mengindikasikan bahwa meningkatnya independensi auditor pada KAP di Provinsi Bali, maka akan dapat menghasilkan laporan keuangan dengan kualitas audit yang tinggi. Begitu juga sebaliknya semakin rendah sikap independensi yang dimiliki oleh auditor di KAP Provinsi Bali, maka akan semakin mengurangi kualitas audit yang dihasilkan.

Hasil penelitian ini sesuai dengan temuan (Janrosl, 2017) dan (A O Enofe et al., 2013) yang mengatakan Independensi berpengaruh positif pada kualitas audit. Semakin tinggi tingkat independensi auditor akan meningkatkan kualitas audit yang dihasilkan auditor. Penelitian serupa yang dilakukan oleh (Iryani, 2017) dan (Susilo \& Widyastuti, 2015) juga menunjukkan hasil yang sama yaitu bahwa independensi auditor semakin meningkat, maka kualitas audit juga meningkat. Seorang auditor yang tidak dapat menjaga independensinya maka laporan keuangan yang diauditnya memiliki kualitas audit yang rendah. Seorang auditor yang dapat menjaga independensinya maka laporan keuangan yang diauditnya memiliki kualitas audit yang tinggi.

Auditor seringkali mengalami konflik kepentingan dimana auditor merasa khawatir akan kehilangan kliennya (Wardhani \& Astika, 2018). Disatu sisi auditor harus menjaga etika profesi, namun disisi lain terkadang harus menghadapi tekanan klien dalam berbagai pengambilan keputusan (Susilo \& Widyastuti, 2015). Penugasan auditor perlu dilakukan rotasi sehingga auditor tidak terlibat terlalu lama dan dekat dengan klien tertentu serta untuk 
menghindari tekanan dari klien tersebut. Rotasi dilakukan sebagai upaya menjaga independensi auditor sehingga kualitas proses audit dapat dipertahankan dan ditingkatkan (Pratistha, 2014).

Hasil analisis regresi moderasi menunjukkan bahwa nilai koefisien regresi pada interaksi variabel pengalaman dan etika auditor sebesar 4,806 dengan tingkat signifikansi t adalah 0,034 lebih kecil dari 0,05. Nilai tersebut mengindikasikan bahwa interaksi variabel pengalaman dan etika auditor memiliki pengaruh yang signifikan pada kualitas audit. Parameter nilai signifikansi interaksi variabel pengalaman dan etika auditor adalah positif, sehingga dapat disimpulkan bahwa etika auditor merupakan variabel moderasi yang dapat memperkuat pengaruh pengalaman pada kualitas audit di KAP Provinsi Bali. Hal ini disebabkan karena hasil penyebaran kuisioner menunjukkan bahwa auditor di KAP Provinsi Bali sudah memiliki pengalaman yang tinggi, kemudian didukung dengan penerapan etika audit yang tinggi sehingga menghasilkan laporan yang memiliki kualitas audit yang tinggi.

Pengalaman kerja secara langsung maupun tidak langsung akan menambah keahlian auditor dalam menjalankan tugasnya. Sementara, etika auditor merupakan nilai-nilai yang dipegang oleh auditor untuk bertindak secara profesional yang sesuai dengan standar profesi. Jadi apabila semakin banyak pengalaman kerja seorang auditor dan semakin tinggi auditor mentaati etika audit maka kualitas audit yang dihasilkan akan semakin baik (Joshua Aronmwan, Oghenekome Ashafoke, \& Oscar Mgbame, 2013). 
Hasil penelitian ini sejalan dengan penelitian yang dilakukan oleh (Alim, 2007) yang mengatakan etika auditor memperkuat pengaruh pengalaman auditor pada kualitas audit yaitu pengalaman dan penerapan etika audit akan memberikan dampak pada setiap keputusan yang diambil dalam pelaksanaan audit sehingga diharapkan setiap keputusan yang diambil adalah merupakan keputusan yang tepat.

Pengalaman kerja auditor merupakan suatu proses pembelajaran dan perkembangan potensi bertingkah laku auditor selama berinteraksi dengan tugas yang dilakukan selama rentang waktu tertentu. (Dewi, 2016) menjelaskan ada tiga indikator mengukur pengalaman kerja auditor yaitu lamanya auditor bekerja, banyaknya penugasan yang ditangani dan banyaknya jenis perusahaan yang pernah diaudit. Sementara, etika auditor merupakan prinsip moral atau nilai-nilai yang dipegang oleh auditor untuk bertindak secara profesional yang sesuai dengan standar profesi.

Pengalaman kerja auditor akan membantu auditor lebih mahir dalam melaksanakan proses audit (Syahmina, 2016). Auditor yang berpengalaman dalam menjalankan tugasnya akan memberikan hasil pemeriksaan yang baik. Artinya, auditor yang memiliki pengalaman lebih banyak akan lebih ahli. Pengalaman kerja secara langsung maupun tidak langsung akan menambah keahlian auditor dalam menjalankan tugasnya. Keahlian membuat auditor mampu mengindikasi risiko-risiko dalam suatu entitas/perusahaan. Pengalaman dan kompetensi tidak menggaransi peningkatan kepatuhan auditor terhadap kode etik (Frisdiantara, Indawati, \& Weeke, 2017). Akuntan publik yang menjunjung tinggi etika profesi 
dan berpengalaman diharapkan dapat menghindari kecurangan, sehingga dapat memberikan pendapat auditan yang benar-benar sesuai dengan laporan keuangan yang disajikan oleh perusahaan.

Hasil analisis regresi moderasi menunjukkan bahwa nilai koefisien regresi pada interaksi variabel independensi dan etika auditor sebesar 5,120 dengan tingkat signifikansi $\mathrm{t}$ adalah 0,006 lebih kecil dari 0,05. Nilai tersebut mengindikasikan bahwa interaksi variabel independensi dan etika auditor memiliki pengaruh yang signifikan pada kualitas audit. Parameter nilai signifikansi interaksi variabel independensi dan etika auditor adalah positif, sehingga dapat disimpulkan bahwa etika auditor merupakan variabel moderasi yang dapat memperkuat pengaruh independensi pada kualitas audit di KAP Provinsi Bali. Hal ini disebabkan karena etika audit mendukung sikap independensi baik itu independensi dalam fakta maupun independensi dalam penampilan sehingga hasil audit menyatakan keadaan yang sebenarnya dan terbebas dari tekanan-tekanan dari pihak terkait sehingga dapat menghasilkan audit yang berkualitas.

Hasil penelitian ini sejalan dengan penelitian yang dilakukan oleh (Pratistha, 2014) dan (M. Nizarul Alim, Trisni Hapsari, 2007) menyatakan bahwa interaksi independensi dan etika auditor berpengaruh positif terhadap kualitas audit. Penelitian ini menunjukkan bahwa kualitas audit di dukung oleh sampai sejauh mana auditor mampu bertahan dari tekanan klien disertai dengan perilaku etis yang dimiliki. Auditor diharapkan tetap menjaga sikap independensinya walaupun dalam proses audit mendapat tekanan dari pihak klien. Auditor sulit 
untuk menjaga tingkat independensi, terutama setelah auditor menjalin kerja sama dengan klien dalam waktu yang terlalu lama dan berhubungan sangat baik dengan klien. Pemberian fasilitas atau hadiah dari klien kepada auditor selama proses audit berlangsung juga akan mempengaruhi independensi auditor. Pemberian hadiah tersebut tidak menutup kemungkinan bahwa sedikit demi sedikit keputusan yang diambil auditor berkaitan dengan tugasnya akan dikendalikan oleh klien. Auditor juga akan sulit mempertahankan independensinya apabila auditor juga memberikan jasa non audit lainnya (Saputra, 2015).

Auditor dalam melaksanakan audit mendapatkan tekanan yang sangat besar dari klien sehingga menyebabkan auditor melakukan tindakan yang bertentangan dengan standar profesional. Auditor yang melawan standar profesional yang telah ditetapkan menghasilkan kualitas audit yang rendah. Namun, semakin tinggi auditor mentaati etika auditor maka independensi akan tetap terjaga sehingga menghasilkan kualitas audit semakin tinggi (Putu \& Purnama, 2013). (Alim, 2007), menjelaskan bahwa independensi adalah sikap mental yang bebas dari pengaruh, tidak dikendalikan oleh pihak lain,tidak tergantung pada orang lain. Independensi juga berarti adanya kejujuran dalam diri auditor dalam mempertimbangkan fakta dan adanya pertimbangan yang objektif tidak memihak dalam diri auditor dalam merumuskan dan menyatakan pendapatnya. Auditor yang mampu bersikap independen menunjukkan bahwa auditor tersebut telah melaksanakan pekerjaannya dengan etika yang baik.

(Dewi, 2016), menyatakan bahwa independensi yang baik serta didukung dengan pemahaman etika auditor yang baik maka akan semakin baik pula kualitas 
auditnya. Semakin tinggi independensi serta etika profesi yang dijunjung auditor maka akan semakin terhindar dari tindakan kecurangan yang dapat memengaruhi pertimbangannya. Etika yang tinggi akan tercermin pada sikap, tindakan dan perilaku oleh auditor itu sendiri. Auditor dengan independensi dan etika yang baik dalam memperoleh informasi mengenai laporan keuangan klien pasti sesuai dengan standar-standar yang telah ditetapkan. Hasil audit sebaiknya ditelaah oleh rekan auditor untuk menjamin bahwa pemeriksaan yang dilakukan telah sesuai dengan standar profesional yang berlaku agar kualitas proses audit dapat dipertahankan dan ditingkatkan.

\section{SIMPULAN}

Simpulan yang dapat diberikan berdasarkan hasil analisis yaitu pengalaman auditor berpengaruh positif pada kualitas audit, independensi auditor berpengaruh positif pada kualitas audit, etika auditor merupakan variabel moderasi yang dapat memperkuat pengaruh pengalaman pada kualitas audit dan etika auditor merupakan variabel moderasi yang dapat memperkuat pengaruh independensi pada kualitas audit di KAP Provinsi Bali.

Berdasarkan simpulan hasil penelitian di atas, maka auditor diharapkan dapat meningkatkan pengalaman dan sikap independensi yang dimilikinya, serta bekerja sesuai dengan etika yang berlaku serta memperhatikan faktor-faktor penting agar menghasilkan kualitas audit yang berkualitas.

Bagi peneliti lain diharapkan agar mengamati faktor-faktor yang mempengaruhi kualitas audit pada populasi yang berbeda serta dapat menambah 
jumlah variabel independen karena hasil $\mathrm{R}^{2}$ yang didapatkan dalam penelitian ini sebesar $63,8 \%$ sehingga disarankan bagi penelitian selanjutnya untuk mengganti variabel moderasi guna mengetahui variabel-variabel lain yang dapat memperkuat atau memperlemah variabel dependen.

\section{REFERENSI}

Adeyemi, S. B., \& Fagbemi, T. O. (2010). Audit Quality, Corporate Governance and Firm Characteristics in. International Journal of Business and Management, 5(5), 169-179. https://doi.org/10.5539/ijbm.v5n5p169

Alim, M. N. (2007). No Title Pengaruh Kompetensi dan Independensi terhadap Kualitas Audit dengan Etika Auditor Sebagai Variabel Moderasi. Simposium Nasional X Makasar, 1-26.

Azza S. M. Gaballa, Z. N., Susilo, P. A., Widyastuti, T., Wardhani, A. A. I. T. W., Astika, I. B. P., Enofe, A. O., ... E-mail, I. (2015). Pengaruh Kompetensi dan Independensi Terhadap Kualitas Audit dengan Etika Auditor sebagai Variable Moderasi. Simposium Nasional Akuntansi 10 (Vol. 3). https://doi.org/10.1017/CBO9781107415324.004

Dewi, A. C. (2016). Pengaruh Pengalaman Kerja, Kompetensi dan Independensi terhadap Kualitas Audit dengan Etika Auditor sebagai Variabel Moderasi pada Auditor Internal Inspektorat Provinsi Daerah Istimewa Yogyakarta. Skripsi, 2016.

Efendy, M. T. (2010). Pengaruh Kompetensi, Independensi, dan Motivasi Terhadap Kualitas Audit Aparat Inspektorat Dalam Pengawasan Keuangan Daerah. Jurnal Ilmiah Akuntansi, 1-109. https://doi.org/10.1017/CBO9781107415324.004

Enofe, A. O., Mgbame, C., Aderin, A., \& Ehi-oshio, O. U. (2013). Determinants of Audit Quality in the Nigerian Business Environment. Reserach Journal of Finance and Accounting, 4(4), 36-44.

Enofe, A. O., Okunega, C. N., \& Ediae, O. O. (2013). Audit Quality and Auditors Independence in Nigeria: An Empirical Evaluation. Research Journal of Finance and Accounting, 4(11), 2222-2847.

Frisdiantara, Indawati, N., \& Weeke, I. S. (2017). frisdiantara (2017).pdf. 
Halim, A., Sutrisno, T., \& Achsin, M. (2014). Effect of Competence and Auditor Independence on Audit Quality with Audit Time Budget and Professional Commitment as a Moderation Variable. Internaiional Journal of Business and Management Invention, 3(6), 64-74.

Hanjani, A., \& Rahardja. (2014). Pengaruh Etika Auditor, Pengalaman Auditor, FEE Audit, dan Motivasi Audit Terhadap Kualitas Audit (Studi Pada Auditor KAP di Semarang). Diponegoro Journal of Accounting, 3(2), 111-119.

Harjanto, A. P. (2014). Pengaruh Kompetensi, Independensi, Objektivitas, Akuntabilitas Dan Integritas Terhadap Kualitas Audit Dengan Etika Auditor Sebagai Variabel Moderasi ( Studi Empiris KAP di Semarang ), 3, 1-12.

Hassan, M. u s a A. d e i z a F. a r o u k a n d S. U. (2014). Impact of Audit Quality and Financial Performance of Quoted Cement Firms in Nigeria. International Journal of Accounting and Taxation, 2(2), 1-22.

Iryani, L. D. (2017). The Effect of Competence , Independence, and Professional Auditors to Audit Quality. Ournal of Humanities and Social Studies, 01(01), $1-4$.

Janrosl, V. S. E. (2017). Pengaruh Akuntabilitas, Independensi, Pengalaman Kerja Dan Standar Audit Terhadap Kualitas Audit Pada Kantor Akuntan Publik Kota Batam, 6(1), 156-163.

Joshua Aronmwan, E., Oghenekome Ashafoke, T., \& Oscar Mgbame, C. (2013). Audit Firm Reputation and Audit Quality. European Journal of Business and Management, 5(7), 2222-2839.

M. Nizarul Alim, Trisni Hapsari, L. P. (2007). Pengaruh Kompetensi dan Independensi Terhadap Kualitas Audit dengan Etika Auditor sebagai Variable Moderasi. Simposium Nasional Akuntansi 10, 53(9), 1-26. https://doi.org/10.1017/CBO9781107415324.004

Muliani, D. M., Sujana, E., \& Purnamawati, I. G. A. (2015). Pengaruh Pengalaman, Otonomi, Dan Etika Profesi Terhadap Kinerja Auditor ( Studi Empiris Pada Kantor Akuntan Publik Di Provinsi Bali ), 3(1), 1-11.

Pradipta, G., \& Budiartha, i ketut. (2016). Tekanan Anggaran Waktu Sebagai Pemoderasi Pengaruh Profesionalisme dan Pengalaman Audit Pada Kualitas Audit. E-Jurnal Akuntansi Universitas Udayana, 15(3 JUNI), 1740-1766 2302-8556.

Pratistha, K. D. (2014). Pengaruh Independensi Auditor Dan Besaran Fee Audit Terhadap Kualitas Proses Audit beberapa tahun terakhir dengan adanya keterlibatan akuntan publik didalamnya . Teori melalui penerbitan dan 
penerapan beberapa aturan , seperti penerbitan Sarbanes-Oxley Ac, 3, 419428.

Putu, N., \& Purnama, I. (2013). Pengaruh Kompetensi Dan Independensi Auditor Pada Kualitas Proses Audit Fakultas Ekonomi Universitas Udayana ( Unud ), Bali , Indonesia Fakultas Ekonomi Universitas Udayana ( Unud ), Bali , Indonesia mencakup pengetahuan dan pengalaman dalam bidang audit. Auditing: A Journal of Practice \& Theory, 1, 136-158.

Riduwan, A. (2017). The Influences of Competence, Independence, Due Professional Care, and Time Budget toward Audit Quality: Psychological Condition As The Moderating Variables, 19(8), 87-99. https://doi.org/10.9790/487X-1908058799

Saputra, W. (2015). The Impact Of Auditor 's Independence On Audit Quality: A Theoretical Approach. International Journal of Scientific \& Technology Research, 4(12, DECEMBER 2015), 348-353.

Septiani, F., \& Juliarsa. (2014). Fakultas Ekonomi dan Bisnis Universitas Udayana ( Unud ), Bali , Indonesia transaksi-transaksi keuangan yang terjadi selama tahun berjalan. Laporan Keuangan ), yang diterapkan secara konsisten dan tidak mengandung kesalahan dalam kegiatan perusahaan . Ma, $1,41-58$.

Smii, T. (2016). the Impact of the Audit Quality on That of the Accounting Profits: the Case of Companies Listed on the Tse. International Journal of Managing Value and Supply Chains (IJMVSC), 7(1). https://doi.org/10.5121/ijmvsc.2016.7104

Susilo, P. A., \& Widyastuti, T. (2015). Integritas, Objektivitas, Profesionalime Auditor dan Kualitas Audit di Kantor Akuntan Publik Jakarta Selatan. Jurnal Riset Akuntansi Dan Perpajakan JRAP, 2(1), 65-77. https://doi.org/ISSN 2339-1545

Syahmina, F. (2016). Pengaruh Pengalaman, Etik Profesi, Objektifitas Dan Time Deadline Pressure Terhadap Kualitas Audit. Jurnal Ilmu Dan Riset Akuntansi, 5(4), 1-20.

Tjun, L. T., Marpaung, E. I., \& Setiawan, S. (2012). Pengaruh Kompetensi dan Independensi Auditor Terhadap Kualitas Audit Lauw Tjun Tjun Elyzabet Indrawati Marpaung. Akuntansi, 4(1), 33-56. https://doi.org/10.1017/CBO9781107415324.004

Usman. (2016). Effect Of Independence And Competence The Quality Of Internal Audit: Proposing A Research Framework, 5(02), 221-226. 
Utama, I. M. K. (2015). Fakultas Ekonomii dan Bisnis Universitas Udayanaa ( Unud ), Bali , Indonesia Fakultas Ekonomii dan Bisnis Universitas Udayanaa ( Unud ), Bali , Indonesia laporan keuangan yang akan disajikan dan semakin peka untuk menemukan, 1, 115-129.

Wardhani, A. A. I. T. W., \& Astika, I. B. P. (2018). Pengaruh Kompetensi, Akuntabilitas dan Independensi pada Kualitas Audit dengan Etika Auditor Sebagai Variabel Moderasi. E-Jurnal Akuntansi Universitas Udayana, 23, 31-59.

Wiratama, W. J. (2015). Professional Care Dan Akuntabilitas Terhadap Kualitas Audit, E-Jurnal Akuntansi Universitas Udayana, 1, 91-106. 